\title{
QUESTIONING FINANCIAL EDUCATION SYSTEM IN INDONESIA: AN ANALYSIS OF STUDENTS' PERSONAL FINANCIAL LITERACY
}

\author{
Murviana Koto ${ }^{1}$, Marliyah $^{2}$, Asma Ardiana $^{3}$ \\ University of Muhammadiyah Sumatera Utara \\ murvianakoto@umsu.ac.id ${ }^{1}$, marliyah@uinsu.ac.id ${ }^{2}$,dianaharahap04@yahoo.com ${ }^{3}$
}

\begin{abstract}
The ability to manage finances becomes a very important thing to learn today. The complexity of a growing variety of financial products and services in society demands a strong foundation of sound financial understanding. The low level of financial literacy in Indonesia has not yet made personal finance a part of the mandatory lessons taught in schools or colleges. This study will look at how the level of personal finance student literacy in one of the largest private universities in Sumatera Utara. The study was conducted on the faculty of economics and business students of the final semester, which means that it has obtained various subjects that support the personal finance level of student literacy. The results of this study indicate that the level of students' personal financial literacy is low. That is, this study further emphasizes that the education taught has not been able to answer the need to improve the personal financial literacy students.
\end{abstract}

Keyword: Personal Financial literacy Students, Financial Literacy, Financial Education

\section{INTRODUCTION}

Today, the ability to manage finances becomes very important. Financial difficulties are not only caused by low income, but problems often arise from miss management mistakes, such as the absence of a financial management plan, the misuse of credit, the mistake in choosing an investment based on one's personal characteristics and even mistakes due to lack of ability to see the health of an institution and becomes very easy to believe in institutions that offer services or investments that led to the occurrence of fraud.

The complexity of a growing variety of financial products and services in society demands a strong foundation of sound financial understanding. The initial filter to prevent potential fraud should start from yourself through financial education. Financial education is a long process that will teach individuals to manage finances well in the future, and this should start at an early age. Lusardi, Michaud, \& Mitchell (2013) said that many today government policy debates, financial knowledge is critically important. Financial literacy knowledge has been taught since early stage in developed countries such as America and Europe. Moreover, National Financial Educator Council (NEC), profit organization which specializes in financial literacy education has curriculum for pre-kindergarten till college and adult (NEC 2014).

Chen and Volpe (1998) have proven that there is a fundamental and systematic shortfall in the financial education system in America and this problem has enormous risk consequences. This is not only found in America, research conducted by Beal \& Delpachitra (2003) towards students in Australia also showed more or less the same results. The lack of personal finance education puts students in Australia unskilled, and does not understand how to manage their personal finances, and this condition tends to negatively impact their future lives and also adversely affects economic growth in the country.

Several studies later proved that teaching on personal finance will help students in managing their personal finances. For example, a study of students in Turkey. Selcuk \& Yilmas (2014) found that students who have received subjects related to financial management in college tend to achieve higher literacy finance rates than students who have not received the lesson. National surveys in various countries also show more or less similar. This is what drives these countries to make policies about the need for personal finance teaching. 
In Indonesia, the 2016 National Financial Literacy Survey conducted by the Financial Services Authority (OJK) provides a portrait of the current state of financial literacy in Indonesia. Indonesia's financial literacy index is only about $29.7 \%$, which means that from every 100 people, only about 29 people have good literacy levels. Under these conditions, it can be concluded that the Indonesian people do not yet have sufficient knowledge in optimizing the money for productive activities, nor do they understand well the various products and financial services offered by formal financial institutions and are more interested in investment offers other potentially disadvantageous (OJK 2016).

The low level of financial literacy in Indonesia has not yet made personal finance a part of the mandatory lessons taught in schools or colleges. The lesson is still in the form of socialization and non-formal education. One of them is the Government of Indonesia program through the Financial Services Authority (OJK) which since 2013 has conducted various educational activities in 144 cities across Indonesia. These activities are conducted as evidence of the Government of Indonesia's commitment to improve the financial literacy index in the community (OJK 2017).

The activities carried out by OJK show evidence that the government is aware that education to improve financial literacy is needed by the people of Indonesia, but education takes a long time, especially because financial problems will be attached to one's behaviour. This study will look at how the level of personal finance student literacy in one of the largest private universities in North Sumatra. The study was conducted on the faculty of economics and business students of the final semester, which means that it has obtained various subjects that support the personal finance level of student literacy.

\section{LITERATURE REVIEW}

Financial literacy is the skill to read, analyze, manage and communicate personal finance condition. Financial literacy also shows skill to choose wisely from various kind of financial management while discussing conditions and things related to finance management and other economy problem. The purpose is to plan good financial planning and financial welfare in the future (Vitt et al, in Huston: 2010).A person with a low level of financial literacy tends to unconsciously make mistakes related to finances. More likely than not to engage in recommended financial practices, and less likely to cope with sudden economic shocks

Widayati (2012) explains that learning in universities plays an important role in the process of forming the Student Financial Literacy. Students live in a diverse and complex economic environment so that an increasing need for financial education is needed. Effective and efficient learning will help students have the ability to understand, assess and act in their financial interests. The existence of good knowledge since the early expected students can have a prosperous life in the future.

Krishna et al. (2010) mention that financial literacy will help person to avoid financial problem. Moreover, financial problem is not only about low income. But also, arise from personal financial management mistake such as credit card misuse or no financial planning. This financial problem can cause stress and inferiority. Financial Literacy is not the same as Financial Education. Hung (2009) in his research explains the difference between Financial and Financial Education: Financial Literacy is the ability to use the knowledge and skills to manage financial resources effectively and for financial welfare for life.

While Financial Education is a process undertaken by someone to increase their understanding of financial concepts, and to understand the choice of available financial products and services, to have the ability to make good financial decisions and avoid the trap of offering financial products and services that are not healthy. Understand how to deal with or seek information and assistance in order to improve the current and long-term financial well-being.

\section{OBJECTIVES}

This study would like to see how the level of financial literacy students of the Faculty of Economics, University of Muhammadiyah Sumatera Utara, then this study will also see how the level of student financial literacy by sex, residence, GPA, father education, mother education and parent income. 


\section{RESEARCH METHODOLOGY}

\section{Design of Research}

This study is descriptive research which aims to present picture about social setting or relationship between phenomena. This study would like to see how the level of financial literacy students of the Faculty of Economics, University of Muhammadiyah Sumatera Utara, then this study will also see how the level of student financial literacy by sex, residence, GPA, father education, mother education and parent income.

The population in this research is the final semester student of bachelor degree, Management study program, Faculty of Economics and Business, University of Muhammadiyah Sumatera Utara (UMSU). The population in this research is 900 students, and primary data sampling is done to 90 students using accidental sampling. This research use survey method by using questionnaire. The distribution of questionnaires was conducted from January to February 2018.

\section{Hypotesis}

The hypotheses in this study are as follows:

H1: Gender affects students' financial literacy level

H2: Residence affects students' financial literacy level

H3: GPA affects students' financial literacy level

H4: Father's education affects students' financial literacy level

H5: Mother's education affects students' financial literacy level

H6: Parents' income affects students' financial literacy level

\section{Data Analysis Method}

The data were analyzed using descriptive analysis and using SPSS software. Descriptive statistics provide an overview of the data seen from the mean, median, mode, standard deviation, maximum and minimum. Descriptive statistics are statistics that describe or describe data into a more clear and easy to understand information.

This study also used chi square analysis. Chi-square test will be used to test the relation or influence of two variables, and Chi-Square will also be used to measure the strength of the relationship between one variables and other variables (Santoso 2006). The following is the chi square testing criteria by looking at the level of significance $(\alpha)$ :

If $p \leq 0.05$, then Ho is rejected

If $\mathrm{p} \geq 0.05$, then Ho is accepted

Chi square test was conducted to test the relation between gender factor, residence, GPA, father's and mother's education and Parents income with student's financial literacy level.

\section{Research Variable}

Student financial literacy is the dependent variable in this study. Financial literature is defined as the ability of a person to choose and make wise decisions about the management and use of personal finance. In this study, the variables were measured using a literacy financial questionnaire related to basic personal finance, income, spending, credit, debt, saving, investment and insurance.

Measurements of variables were performed based on the percentage of truths from respondents' answers from 26 multiple choice questions based on research (Chen \& Volve 1998; Nababan \& Sadalia 2012; Margaretha \& Pambudhi, 2015). Respondents' answers to personal financial literacy questionnaires were then divided into three categories:

1. $<60 \%$, indicating the level of individual financial literacy at a low level

2. $60 \%-79 \%$, indicating the level of individual financial literacy at the intermediate level/ medium level

3. $>80 \%$, indicating that the level of individual financial literacy is at a high level. 
The independent variable in this study consists of six variables. Each variable is classified as follows:

1. Sex, this variable explains the classification of the sex of the respondent, male or female.

2. Residence, this variable describes the student's residence during the lecture. Variable in is divided into two categories: 1). Live with parents/family, 2). Live independently in boarding/rented house.

3. GPA, this variable describes the GPA (grade point average) of the respondent at this time. Variable in is divided into two: 1). $\leq 3,00$ or 2 ). $>3,00$

4. Fathers Education, this variable describes the last level of education Father of the respondent. These variables are divided into two categories: 1). Primary school-Junior high school, 2). Senior high school-Bachelor

5. Mothers Education, this variable describes the last level of education Father of the respondent. These variables are divided into two categories: 1). Primary school-Junior high school, 2). Senior high school-Bachelor

6. Parent income, this variable describes the income level of Parents obtained each month. The variables are divided into two categories: 1). $\leq \mathrm{Rp} 5,000,000$. - and 2). $>\mathrm{Rp5}, 000,000$.

\section{ANALYSIS AND DISCUSSION}

\section{Characteristic Respondence}

The following is a table of respondent characteristics:

\begin{tabular}{|c|c|c|}
\hline Variables & $\begin{array}{c}\text { Number of } \\
\text { Participants }\end{array}$ & Percentage \\
\hline \multicolumn{3}{|l|}{ Gender } \\
\hline Male & 46 & $51,1 \%$ \\
\hline Female & 44 & $48,9 \%$ \\
\hline \multicolumn{3}{|l|}{ Residence } \\
\hline Live with parents/family & 31 & $34,4 \%$ \\
\hline Live independently & 59 & $65,6 \%$ \\
\hline \multicolumn{3}{|l|}{ GPA } \\
\hline$\leq 3,00$ & 37 & $41.1 \%$ \\
\hline$>3,00$ & 53 & $58,9 \%$ \\
\hline \multicolumn{3}{|l|}{ Fathers' Education } \\
\hline Elementary School - Junior High School & 18 & $20 \%$ \\
\hline Senior High School - Bachelor & 72 & $80 \%$ \\
\hline \multicolumn{3}{|l|}{ Mothers' Education } \\
\hline Elementary School - Junior High School & 26 & $28,9 \%$ \\
\hline Senior High School - Bachelor & 64 & $71,1 \%$ \\
\hline \multicolumn{3}{|l|}{ Parents' Income } \\
\hline$\leq \mathrm{Rp} 5,000,000 .-/$ month & 10 & $11,1 \%$ \\
\hline$>\mathrm{Rp} 5,000,000 .-1$ month & 80 & $88.9 \%$ \\
\hline
\end{tabular}

Table 1: RespondenceProfiles

Based on the respondent's data, the distribution of questionnaires based on gender is slightly different or almost equal. The number of male respondents is 46 people or $51.1 \%$ and the number of female respondents is 44 people or $48.9 \%$ of the total sample of 90 people.

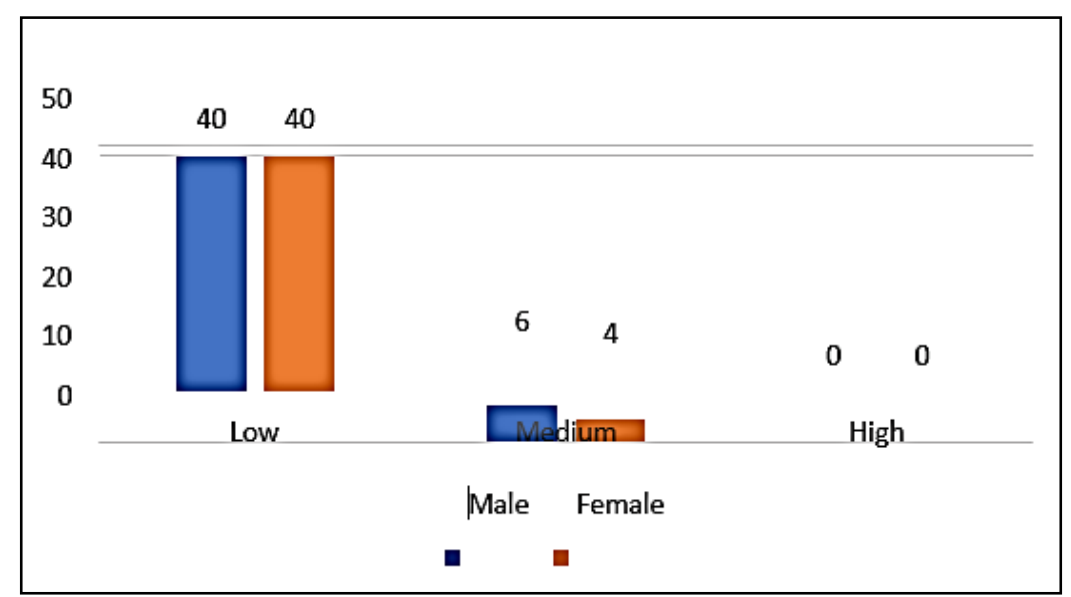

Figure 1: Students' Financial Literacy based on Gender 
Residence is a student residence during the course. Most of the students live alone during college and these groups tend to be more independent in managing their finances because they are fully involved in everyday financial transactions. The number of students who live independently is more dominant than the students who live with parents, that is as many as 59 students or $65.6 \%$ of respondents are independent living alone and students living with their parents is 31 respondents or $34.4 \%$.

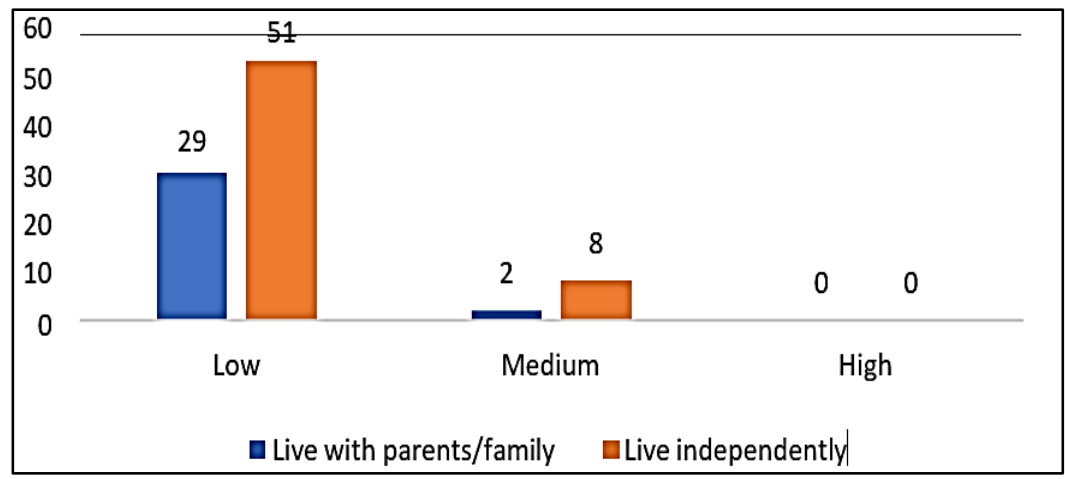

Figure 2: Students' Financial Literacy based on Residence

Based on the level of financial literacy, students with medium literacy medium rate more on students who have a place to live independently during his lecture. The cumulative grade index is grouped into two parts: $<3.00$ and $>3.00$. Based on the data can be seen that there are 37 respondents who have GPA below 3.00 or about $41.1 \%$ and 53 people or $58.9 \%$ of respondents have GPA above 3.00 .

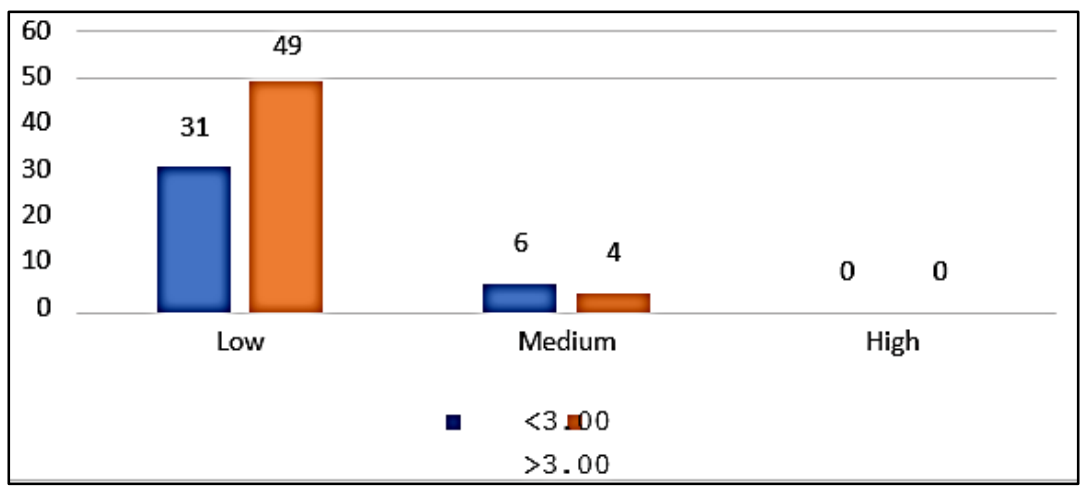

Figure 3: Students' Financial Literacy based on GPA

Based on the data level of parent's education can be seen that the majority of respondents have parents with a minimum education level is Senior high school or bachelor. And based on the income of parents also seen that the highest amount of income is over Rp5,000,000 - per month.

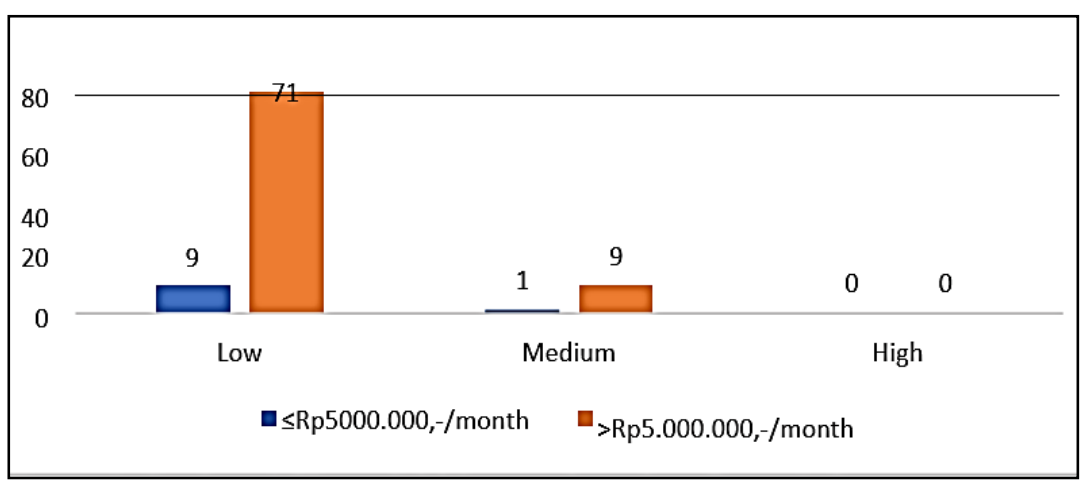

Figure 4: Students' Financial Literacy based on Parent's Income 
The following is the percentage of respondents who answered correctly for each question posed to the respondent:

\begin{tabular}{|c|c|c|c|c|}
\hline \multirow{2}{*}{\multicolumn{2}{|c|}{ Financial Literacy Area }} & \multicolumn{3}{|c|}{ Rate of Financial Literacy } \\
\hline & & $<60$ & $60-79$ & $>80$ \\
\hline \multicolumn{5}{|c|}{ a. Basic Personal Finance } \\
\hline 1 & Financial Knowledge & 52,2 & & \\
\hline 2 & Education as part of investment & 38 & & \\
\hline 3 & Liquidity of asset & 32 & & \\
\hline 4 & Inflation to society & 38 & & \\
\hline 5 & Inflation to purchasing & 18,9 & & \\
\hline \multirow{2}{*}{6} & Knowledge of compound interest & 27 & & \\
\hline & Mean: & 34,35 & & \\
\hline \multicolumn{5}{|c|}{ b. Money Management } \\
\hline 7 & Revenue & 58 & & \\
\hline & Source of income & 44,4 & & \\
\hline & Expenditure instruments & & 70 & \\
\hline & Emergency Fund & 48,9 & & \\
\hline 11 & Budgeting & 27,8 & & \\
\hline \multirow[t]{2}{*}{12} & ATM characteristic & 54,4 & & \\
\hline & Mean: & 50,59 & & \\
\hline & Debt and Credit & & & \\
\hline 13 & Credit feasibility & 40 & & \\
\hline 14 & Borrowing cost & 41,1 & & \\
\hline 15 & Credit rules & 19 & & \\
\hline & Credit card & 37,8 & & \\
\hline & Mean: & 34,48 & & \\
\hline \multicolumn{5}{|c|}{ d. Savings and Investments } \\
\hline 17 & Banking institutions & 29,9 & & \\
\hline 18 & Capital market institutions & 18,9 & & \\
\hline 19 & Characteristics of deposits & 41,1 & & \\
\hline 20 & Characteristic of investment & 41,1 & & \\
\hline 21 & Interest rates and bonds & 20 & & \\
\hline 22 & Investment strategy & 20 & & \\
\hline & Stock market & 50 & & \\
\hline & Mean & 31,43 & & \\
\hline & Risk Managemen & & & \\
\hline 24 & Insurance & & 66,7 & \\
\hline & Rule of insurance & 27,8 & & \\
\hline & Risk & 36,6 & & \\
\hline & Mean: & 43,7 & & \\
\hline
\end{tabular}

Table 2: Source: Primary data processing results, 2018

Based on the percentage of respondents' answers, there are only two items of questions that have a value of more than 60 , namely the instrument of expenditure and insurance purposes. The lowest percentage of answers is on the question items about inflation and purchasing power and on the question items on loans and guarantees, which is only $18.9 \%$.

\section{Results of Students' Financial Literacy Survey}

Financial Literacy Level is calculated based on the correct respondent's answer then divided by all questions. Chen and Volpe (1998) categorize financial literacy into three groups: 1) <60\% which 
means that individuals have low financial knowledge, 2) $60 \%-79 \%$ means the individual has knowledge about the financial being, and 3)> 80\% indicating that the individual has a high financial

knowledge. Overall, the results of literacy finance in students at the University of Muhammadiyah North Sumatra as follows:

\begin{tabular}{lcc}
\multicolumn{2}{c}{ Student Financial Literacy Level } \\
\cline { 2 - 3 } Category & Nos. & Percentage (\%) \\
\hline Low & 80 & $88,89 \%$ \\
Medium & 10 & $11,11 \%$ \\
High & 0 & $00,00 \%$ \\
\hline Total & 90 & $100 \%$ \\
\hline \multicolumn{2}{c}{ Statistic Descriptive } & Financial Literacy (\%) \\
\hline Minimum & $7,69 \%$ \\
Maximum & $73,08 \%$ \\
Mean & $38,08 \%$ \\
Deviation Standard & $15,31 \%$ \\
\hline
\end{tabular}

Table 3: Student Financial Literacy Level

The results of this study indicate that the majority of students' financial literacy rate is at a low level $(88.89 \%)$. This research is in line with the research that has been done by Margaretha \& Pambudhi (2015) who measured the financial literacy level of student of economic faculty of Trisakti University, found that most students have low financial literacy level. This level influenced by some factors.

\section{Chi-Square Test}

Chi Square test was conducted to find out whether there is association between demography factor with level of student's financial literacy. Demographic factors used in this study are gender, residence, GPA, father's and mother's education and income parents. The following is a summary of Chi Square test results on demographic factors and financial literacy levels:

\section{Chi Square}

\begin{tabular}{lll}
\hline Variables & Chi Square & Result \\
\hline Gender x Financial Literacy & 0,000 & H1 acceptable \\
Rate & 0,004 & H1 acceptable \\
Residence x Financial Literacy & 0,314 & H1 deny \\
Rate & 0,032 & H1 acceptable \\
GPA x Financial Literacy Rate & 0,034 & H1 acceptable \\
Father's education x Financial & 0,022 & H1 acceptable \\
Literacy Rate & \\
Mother's education x Financial & \\
Literacy Rate & \\
Parent's Income x Financial & \\
Literacy Rate & & \\
\hline
\end{tabular}

Table 4: Chi Square

Based on the above results, $\mathrm{H} 1$ accepted means the demographic factors that become variable in this study relate to the level of financial literacy students. There is a significant relationship between gender, residence, father's and mother's education and Parents income with the level of student financial literacy, but there is no relationship between GPA with the level of student financial literacy. 


\section{CONCLUSIONS}

This study shows at how the financial literacy level of final semester students, Management study program, Faculty of Economics and Business, University of Muhammadiyah Sumatera Utara (UMSU). The contribution of gender, residence, father's and mother's education and parents' income factors influences the financial level of student literacy. Factor analysis in this study found that $88.89 \%$ of students' financial literacy level is at low level. The lowest percentage of answers is the general knowledge of finance and saving and investment issues.

Based on research done to 90 final semester students, Management study program, Faculty of Economics and Business, we can conclude that the lesson learned by students is still in the form of knowledge about economics in general not related to improvement of personal financial literacy. Students have taken many lessons during their studies in faculty of economics and business and even got a good enough GPA, but they have not received special instruction on how the application of science in everyday life. It means that the education that is taught has not been able to answer the need to improve the personal finance of the student literacy.

\section{REFFERENCE}

Beal, Diana, P \& Delphacitra, Sarath, B. 2003. Financial Literacy Among Australian University Student. Economic Papers 22(1): 65-78.

Chen, H. R.P. Volpe. 1998. An Analysis Of Personal Financial Literacy Among College Students. Financial Services Review 7(2): 107-128.

Chen, Haiyang \& Volpe, Ronald. P. 2002. Gender Differences In Personal Financial Literacy Among College Students. Financial Services Review 11: 289-307.

Krishna, A., Rofaida, R., \& Sari, M. 2010. Analysis Of The Level Of Financial Literacy Among Students And The Factors That Influence. Proceedings Of The 4th International Conference On Teacher Education: Join Conference Upi \& Upsi Bandung, Indonesia.

M. Van Rooij, A. Lusardi, R. Alessie. 2008. Financial Literacy And Stock Market Participation. University Of Michigan Retirement Research Center Working Paper, (2007): 162.

M. A. Hilgert, J. M. Hogarth \& S.G Beverly. 2003. Household Financial Management: The Connection Between Knowledge And Behavior. Federal Reserve Bulletin 89: 309-322.

Margaretha, F., Pambudhi, R. A. 2015. Financial Literacy Level On Student S-1 Faculty Of Economics. Jmk. 17(1): 76-85

Mason, C. L.J., Wilson, R. M. S. 2000. Conceptualizing Financial Literacy Business School Research Series.

Nidar, S. R. \& Bestari, S. 2012. Personal Literacy Among University Students (Case Study At Padjajaran University Students, Bandung, Indonesia. World Journal Of Social Science 2(24): 162-171.

Nidar, S. R., \& Bestari, S. 2012. Personal Literacy Among University Students (Case Study At Padjajaran University Students, Bandung, Indonesia. World Journal Of Social Science, 2(4): 162-171.

Ojk .2016. National Survey Of Literacy And Financial Inclusion. Accessed 24 Jun 2017.Www.Ojk.Go.Id

Ojk. 2017. Mei 10. Siaran Pers: Global Inclusion Awards 2017. Retrieved From Http://Www.Ojk.Go.Id/Id/Berita-Dan-Kegiatan/Siaranpers/Documents/Pages.Siaran-PersGlobal-Inclusion-Awards-2017\%2C-Pengakuan-Internasional-Untuk-Program-InklusiKeuangan Indonesia/Sp\%2050\%20Dkns\%20Ojk\% 20V\%202017.Pdf.

Ojk. 2017, January 24. Siaran Pers: Ojk: Indeks Literasi Dan Inklusi Keuangan Meningkat. Retiered From Http://Www.Ojk.Go.Id/Id/Berita-Dan-Kegiatan/Siaran-Pers/Pages/Siaran-Pers- OjkIndeks-Literasi-Dan-Inklusi-Keuangan-Meningkat.Aspx

Remund, D. L. 2010. Financial Literacy Explicated: The Case For a Clear Definition In An Increasingly Complex Economy. The Journal Of Consumer Affair 44(2): 276-295.

Sabri, M. F., Othman, M. A., Masud, J.,Paim, L., Macdonald, M., \& Hira, T.K. 2008. Financial Behavior And Problems Among College Students In Malaysia: Research And Education Implication. Consumer Interest Annual 54:166-170.

Widayati, I. 2012. Factors Affecting The Financial Literacy Of Ub Faculty Of Economics And Business Students. Journal Of Accounting For Education 1(1): 89-99. 